\title{
The Analysis of Forest Land Cover Change And Area Determination of Land Rehabilitation Based on Geographic Information System in Magelang Regency
}

\author{
Lidya Ernawati ${ }^{1}$, Sutrisno Anggoro ${ }^{1,2}$ \\ ${ }^{1}$ Master Program of Environmental Science, School of Postgraduate Study Diponegoro University, Semarang - Indonesia \\ ${ }^{2}$ Management of Water Resources Departement, Faculty of Fisheries and Marine Science Diponegoro University, Semarang - \\ Indonesia
}

\begin{abstract}
Population increased has consequences for the economic development of land demands for agriculture, settlement and other infrastructure. This resulted the change of area land cover which impact on the climate change and decline the environmental quality. Therefore, it is necessary to improve the environment through the land rehabilitation activities. The analysis of land cover change is needed as the first step to identify areas targeted by the land rehabilitation. Geographic information system is used as a spatial based on the appropriate determination of rehabilitation activities
\end{abstract}

Keywords: Land Cover Change; Rehabilitation, Geographic Information System

\section{Introduction}

Magelang regency is located in the central part of Central Java province, ranging between $110^{\circ} 01 ' 51$ "to $110^{\circ} 26^{\prime} 28^{\prime \prime}$ East Longitude and $7^{\circ} 19^{\prime} 13$ "up to $7^{\circ}$ 42'16" South Latitude. Magelang regency altitude ranges from 154-3.296 $\mathrm{m}$ above sea level. The regency is adjacent to Temanggung and Semarang regencies in the north, Semarang and Boyolali regencies in the east, Purworejo Regency and Yogyakarta Special Province in the south then Temanggung and Wonosobo regencies in the west. While in the middle of Magelang Regency there is Magelang Municipality. The total area of Magelang regency is 108,573 ha with most of the area are mountains with steep slopes. There are 3 mountains included in Magelang Regency area namely Mount Merapi, Mount Merbabu and Mount Sumbing. With its mountainous terrain and fertile soil, Magelang regency is a fertile agricultural area.

The population regarded as the population census in 2010 was $1,181,916$ people with population growth rate of $0.62 \%$ per year. A $37.78 \%$ total population of Magelang Regency in 2015 make agriculture as the main employment [1]. As a primary source of living in Magelang regency, the land-based sector requires a large area for economic development, which results the increased demand for land for the various commodities production. This increase of land use leads the land conversion use and cover the forests form for agricultural activities and settlements also other wake-up areas. For example, in Merbabu Mount National Park, forest covers only $30 \%$ of the park area with a $3 \%$ deforestation rate per year [2]. Reduced forest area has impact on the environment. The change impacts in forest cover are seen in atmospheric temperature changes, clouds, humidity, circulation, and rainfall. On a regional scale, land cover changes cause a $1{ }^{\circ} \mathrm{C}$ temperature drop in summer and $-0.8^{\circ} \mathrm{C}$ in winter [3], leading to the extreme of floods floods and droughts conditions which increasingly larger and larger volumes in common [4].

The damage condition and pressure on the forest is a challenge in forestry development. The Ministry of Environment and Forestry has made an accelerating effort to reduce and rehabilitate forest destruction through the Priority Policy establishment on Forestry and the National Development Program of the United Indonesia Cabinet, one of which is the forests rehabilitation and the enhancement of the Watershed carrying capacity [5]. Forest and land rehabilitation (RHL) is an effort to restore, maintain and improve forest and land functions. The ultimate rehabilitation goal is to maintain the carrying capacity, productivity and the forests role and land in supporting life platform systems.

Forests have a variety of functions including as a habitat for flora, fauna, water resources, and as a binding element carbon from the air. Carbon is one of the retreat is very important in the process of photosynthesis. In fotosintesi process will occur formation of carbohydrates from carbon dioxide $\left(\mathrm{CO}_{2}\right)$ is obtained from the air and the water absorbed by the roots. These two elements with the help of sunlight, processed in chlorophyll produce carbohydrates as energy for the plant itself.

*Corresponding author: ernawati.lidya@yahoo.com 
Therefore vegetation in the forest area is part of the forest ecosystem which needs to be maintained.

The analysis of land cover change is used to determine the land cover history in an area and changes in land cover occur during a certain period. The analysis of land cover change is needed as the first step to identify areas targeted by land rehabilitation. Geographic information system is used as a spatial based analysis tool so that the determination of rehabilitation activities can be right on target. The results of this analysis can be used as a consideration for the government to conduct land rehabilitation activities as an effort to restore the forest area as

\section{Metode}

This study uses land cover data from 1990 to 2015 from the Environment and Forestry Ministry. This time span is chosen based on the data availability and the consideration within the 25 years span which has been a dynamic land cover change. The analysis of land cover change can be done by overlaying the time series data from three land cover periods (1990, 2000, 2015) and extracting tabular data to analyze the changes in land cover use in the study area.

The area determination for the land rehabilitation plan is carried out by overlaying the 1990 land cover data and 2015 land cover. The land cover type allowed to the land rehabilitation becomes the land rehabilitation activities priority target.

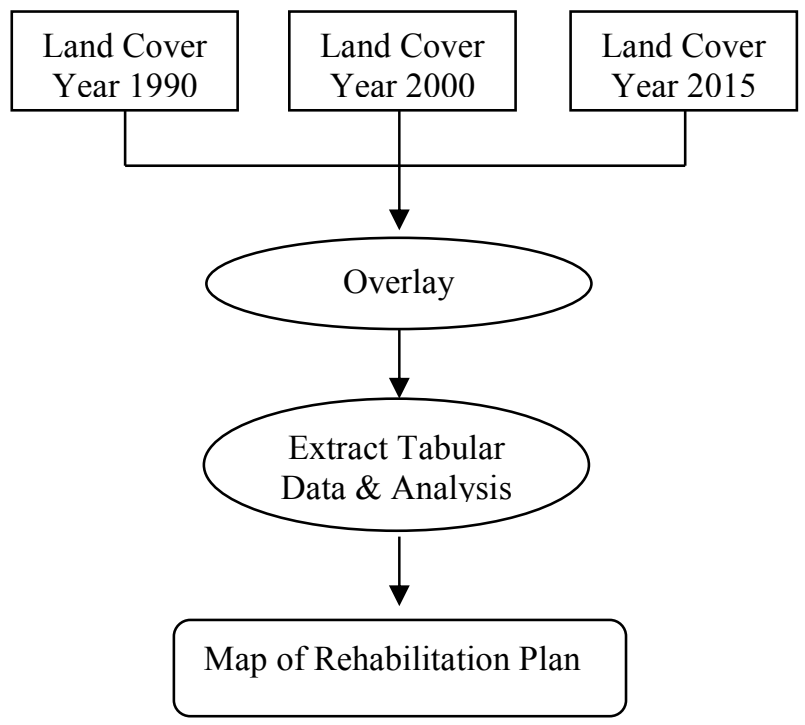

Fig.1. SchematicRepresentation of Methodology

\section{Result and Discusion}

Land is a physical environment includes soil, climate, relief, hydrology and vegetation whereas these factors affect the potential use. The land includes the human activity consequences in the past and present time [6].

Land cover means biophysical cover on the surface of the earth can be observed and as the regulation result, activity, also human treatment conducted on certain types of land cover to undertake the production activities, changes or arrangements in the area (SNI). To classify the land cover various types into a similarity, the land cover classification with a particular system. The classification of forest cover refers to Indonesian National Standard (SNI) 7645: 2010. Forests are a land cover mixed class. At national-scale land cover, which are 7 forest cover classes and 15 non-forest cover classes [7].

\subsection{Land Cover Change}

The existing land cover class in Magelang Regency consists of 8 land cover classes i.e. secondary forest, plantation forest, shrubs, settlement, open land, water body, dryland farming and mixed dryland farming. Land cover in Magelang Regency for the period of 1990, 2000 and 2015 can be seen in the following figure 2 :
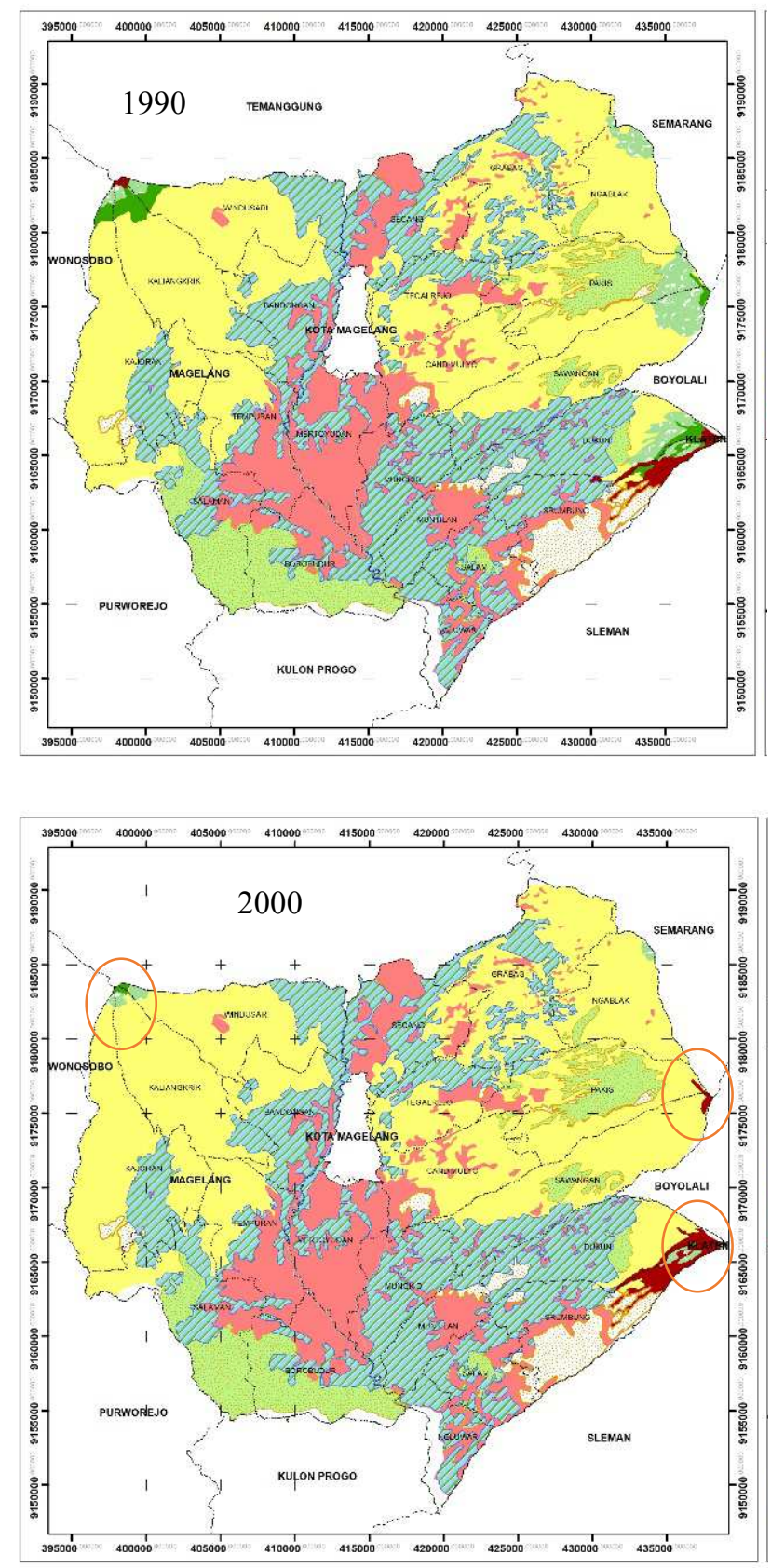


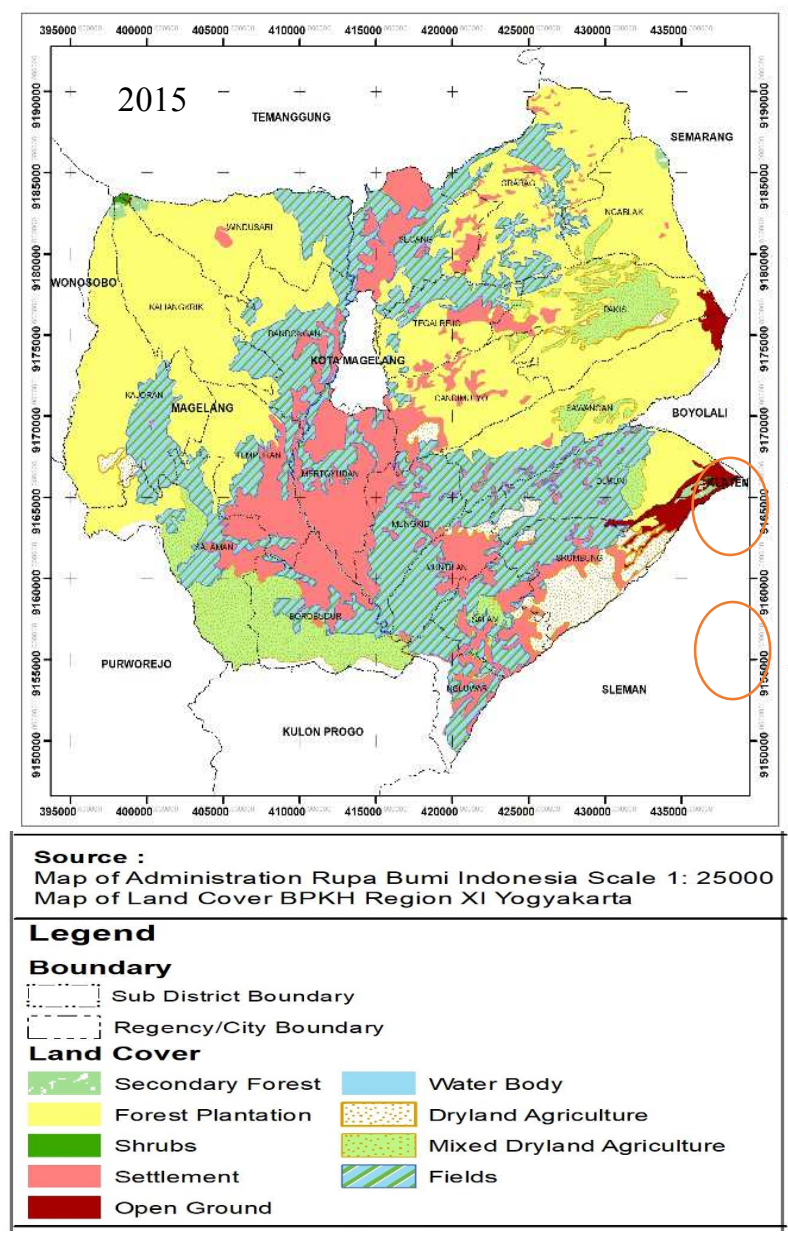

Fig. 2. Land Cover Map 1990-2000-2015

Forest cover in Magelang Regency comprised of secondary forests and plantations. Secondary Forests are forests that grow in areas that have been logged, burned or regenerated from degraded land. The $86 \%$ reduction in secondary forest cover occurred in the 1990-2000 period. In this period, the political and social conditions of the community was in turmoil [8]. This also affects the existence of secondary forest in Magelang regency. Although extents, secondary forest is only of $0.35 \%$ of the total area, but its presence is important for the environment. Secondary forest is located in Merapi National Park and Merbabu National Park. In the period 2000-2015, secondary forest cover did not change much, but still decreased by 30 ha.

Table 1. Land Cover Area 1990, 2000 and 2015

\begin{tabular}{|l|r|r|r|r|r|}
\hline \multirow{2}{*}{ Land Cover } & \multicolumn{3}{|c|}{ Year } & \multicolumn{2}{c|}{$\begin{array}{c}\text { Extent of Land } \\
\text { cover Change } \\
\text { (ha) }\end{array}$} \\
\cline { 2 - 7 } & 1990 & 2000 & 2015 & $\begin{array}{l}1990- \\
2000\end{array}$ & $\begin{array}{l}2000- \\
2015\end{array}$ \\
\hline $\begin{array}{l}\text { Secondary } \\
\text { Forest }\end{array}$ & 2,866 & 392 & 388 & $-2,474$ & -3 \\
\hline $\begin{array}{l}\text { Forest } \\
\text { Plantation }\end{array}$ & 45,147 & 48,263 & 47,925 & 3,116 & -338 \\
\hline Shrubs & 1,054 & 65 & 65 & -990 & 0 \\
\hline Settlement & 18,336 & 18,336 & 18,337 & 0 & 0 \\
\hline Open & 759 & 1,125 & 1,464 & 367 & 339 \\
\hline
\end{tabular}

\begin{tabular}{|l|r|r|r|r|r|}
\hline \multirow{2}{*}{ Land Cover } & \multicolumn{3}{|c|}{ Year } & \multicolumn{2}{c|}{$\begin{array}{c}\text { Extent of Land } \\
\text { cover Change } \\
\text { (ha) }\end{array}$} \\
\cline { 2 - 7 } & 1990 & 2000 & 2015 & $\begin{array}{l}1990- \\
2000\end{array}$ & $\begin{array}{l}2000- \\
2015\end{array}$ \\
\hline Ground & & & & & \\
\hline Water Body & 295 & 295 & 299 & 0 & 4 \\
\hline $\begin{array}{l}\text { Dryland } \\
\text { Agriculture }\end{array}$ & 3,770 & 3,751 & 3,751 & -19 & 0 \\
\hline $\begin{array}{l}\text { Mixed } \\
\text { Dryland } \\
\text { Agriculture }\end{array}$ & 9,245 & 9,245 & 9,244 & 0 & -1 \\
\hline Fields & 29,917 & 29,917 & 29,916 & 0 & -1 \\
\hline
\end{tabular}

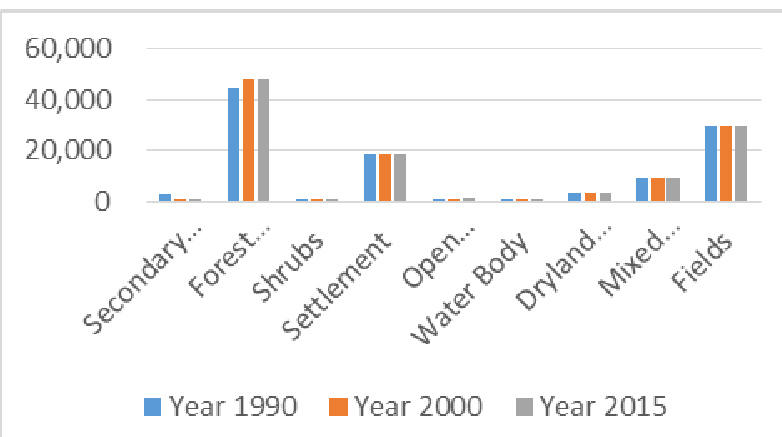

Fig.3. Land Cover Changes Year 1990, 2000 and 2015

Plantations are planted forest areas, including reforestation plantations. The main characteristic of the land cover classes of plantations is land overgrown with a variety of plants but the majority covered by one type of tree. Plantation forest is usually the result of forest reforestation methods by the government and the community for a specific purpose. Plantation forest is the most dominant land cover class in Magelang District. In the period of 1990-2000, an increase of area of 3.116 ha (7\%). This increase was derived from secondary forests being turned into plantations (figure 2). In the period 2000-2015 a decline in plantation forest area of 338 ha.

\subsection{Rehabilitation}

Rehabilitation is defined as an activity intentionally aimed at the regeneration of trees, either naturally and / or artificially, on pastures, shrubs, or barren areas that were formerly forest, in order to increase productivity, livelihoods and / or environmental service benefits [9]. The most important point of this definition is an attempt to restore the area that was once a forest, but at this time in the form of another cover classes. Determination of this rehabilitation area can be done by looking at the history of a region by comparing the condition of land cover within a certain period.

Changes in forest cover from 1990-2015 can be seen in table 2 below :

Table 2. Forms of Land Cover Changes

\begin{tabular}{|c|c|c|}
\hline $\begin{array}{c}\text { Land Cover } \\
1990\end{array}$ & Change of Land Cover 2015 & $\begin{array}{c}\text { Change of } \\
\text { Area (Ha) }\end{array}$ \\
\hline
\end{tabular}




\begin{tabular}{|c|c|c|}
\hline $\begin{array}{c}\text { Land Cover } \\
1990\end{array}$ & Change of Land Cover 2015 & $\begin{array}{l}\text { Change of } \\
\text { Area (Ha) }\end{array}$ \\
\hline \multirow{3}{*}{$\begin{array}{l}\text { Secondary } \\
\text { Forest }\end{array}$} & Secondary Forest & 388 \\
\hline & Plantation Forest & 2,221 \\
\hline & Open Ground & 256 \\
\hline \multirow{3}{*}{$\begin{array}{l}\text { Plantation } \\
\text { Forest }\end{array}$} & Plantation Forest & 45,092 \\
\hline & Open Ground & 54 \\
\hline & Fields & 1 \\
\hline \multirow{3}{*}{ Shrubs } & Plantation Forest & 612 \\
\hline & Shrubs & 8 \\
\hline & Open Ground & 435 \\
\hline \multirow{3}{*}{ Settlement } & Settlement & 18,333 \\
\hline & Water Body & 3 \\
\hline & Fields & 1 \\
\hline \multirow{3}{*}{ Open Ground } & Shrubs & 57 \\
\hline & Open Ground & 700 \\
\hline & Fields & 1 \\
\hline Water Body & Water Body & 295 \\
\hline \multirow{2}{*}{$\begin{array}{l}\text { Dryland } \\
\text { Agriculture }\end{array}$} & Open Ground & 19 \\
\hline & Dryland Agriculture & 3,751 \\
\hline \multirow{2}{*}{$\begin{array}{l}\text { Mixed } \\
\text { Dryland } \\
\text { Agriculture }\end{array}$} & Settlement & 1 \\
\hline & Mixed Dryland Agriculture & 9,244 \\
\hline \multirow{3}{*}{ Fields } & Settlement & 3 \\
\hline & Water Body & 1 \\
\hline & Fields & 29,913 \\
\hline & Total & 111,389 \\
\hline
\end{tabular}

In the period 1990-2015, secondary forests were converted to plantations by $77 \%$ and a small portion became open ground. Secondary forest left only $14 \%$ of its original area (Figure 4). This open land becomes the target area of rehabilitation.

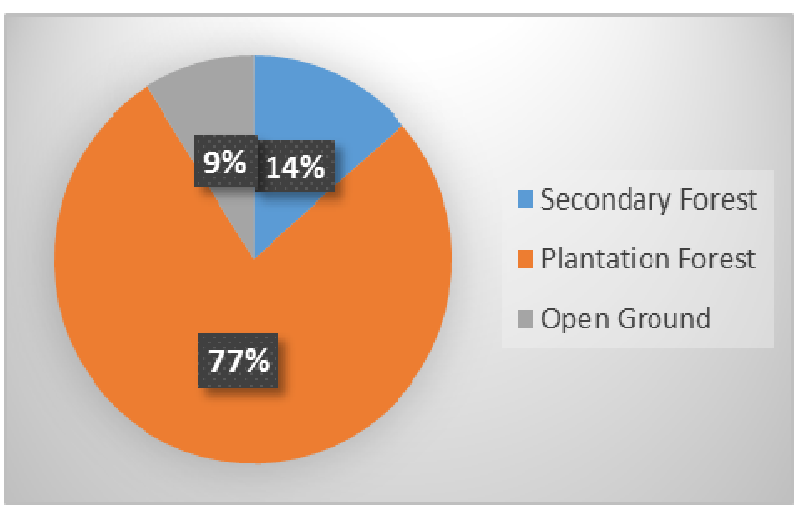

Fig.4. Forms Of Secondary Forest Change

Plantation forest is a land cover area that dominates the area in Magelang regency. Plantations generally grow on people's land. Its existence tends to stabilize over time. Reduction of plantation forests into rice fields only amounted to 1 ha, while the plantation forest into an open area of 54 ha. From this type of forest plant cover, the target of land rehabilitation is an open ground.

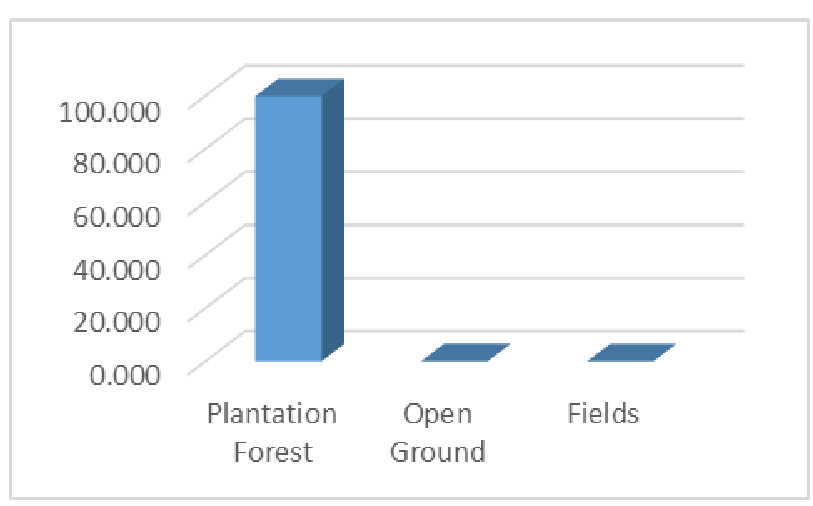

Fig.5. Forms of Plantation Forest Change

The type of land cover that is subject to rehabilitation is open ground and shrubs. From the analysis, an area of 1.529 ha of potential land for rehabilitation areas. Most of the land rehabilitation objectives are open ground. When viewed from its location, open ground is mostly on the slopes of Mount Merbabu and Mount Merapi in the form of land flow/sand. For that required rehabilitation techniques in accordance with these conditions.

Table 3. Rehabilitation Plan

\begin{tabular}{|c|r|}
\hline Land Cover & \multicolumn{2}{|c|}{ Large (ha) } \\
\hline Open ground & 1,464 \\
\hline Shrubs Sum & 65 \\
\hline \multicolumn{2}{|c|}{1,529} \\
\hline
\end{tabular}

Forest areas in the Mount Merbabu National Park are already very open and overgrown with shrubs and grasslands. The variety of tree species is very low [10]. This condition shows that this forest area experienced a very large disturbance. Mount Merbabu experienced several fires which were allegedly caused by human activities. In addition to fires, disturbances to forests are tree theft and theft of ornamental plants.

Mount Merbabu National Park and Mount Merapi National Park have very important ecological functions. Inside the area, there are springs that are used by the surrounding community. Therefore, the existence of this forest is very important for the survival of the surrounding community. 

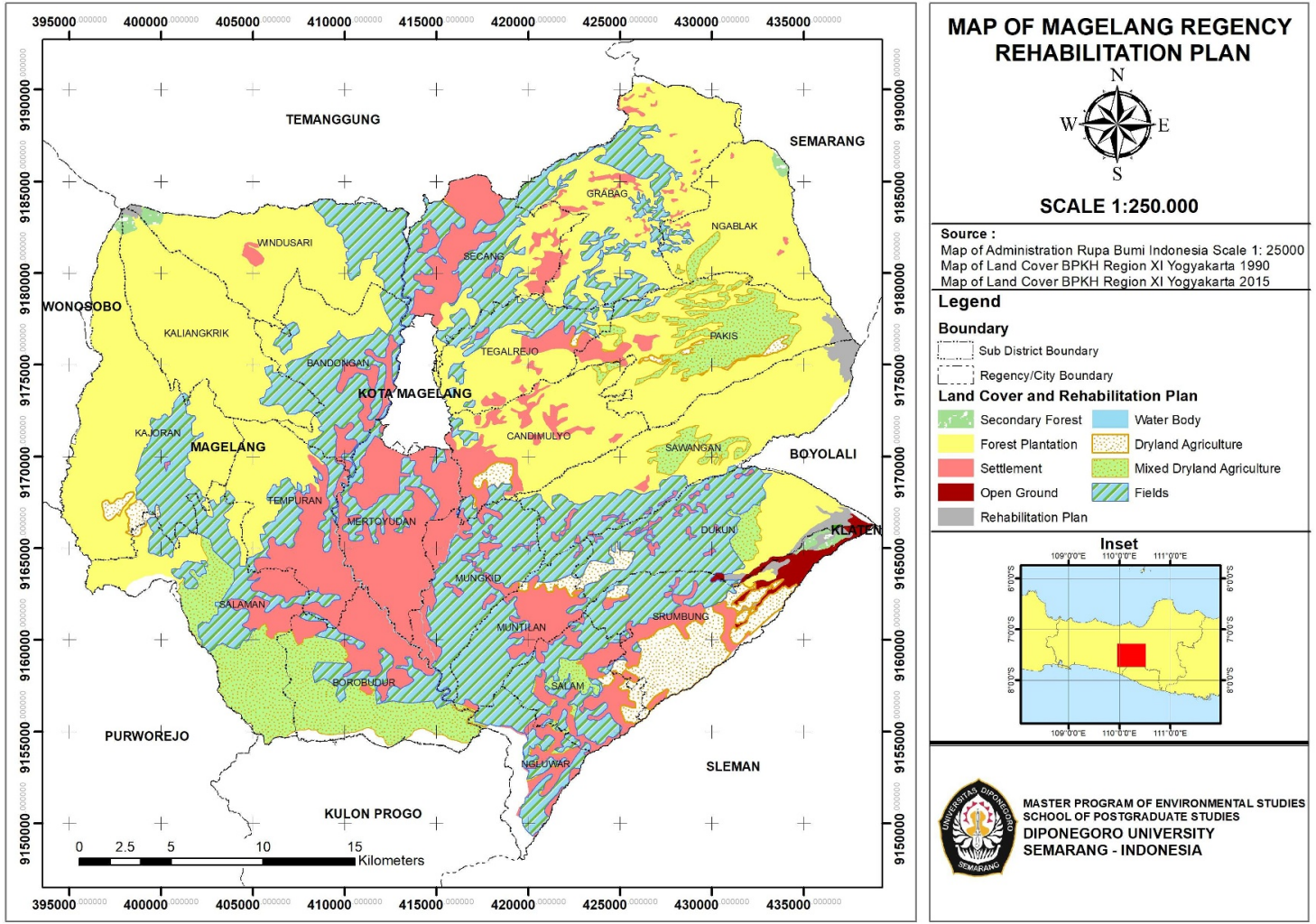

Fig.6. Map of Magelang Regency Rehabilitation Plan

\section{Conclusion}

The condition of land cover change in Magelang regency can be analyzed by using land cover data. The results of the analysis can be used to monitor land use conditions and the impact of changes from the land cover. Over a period of 25 years there has been a decrease in secondary forest area of 2.477 ha and a decrease of 55 ha of plantation forest. 1.529 ha of land can be reforested through rehabilitation activities.

\section{References}

1. Badan Perencanaan Pembangunan Daerah Kabupaten Magelang. Statistik Umum Kabupaten Magelang. (2016)

2. M. Alkaf, K. Munibah, O. Rusdiana. Model Spasial Perubahan Penggunaan Lahan Di Taman Nasional Gunung Merbabu dan Daerah Penyangganya. Majalah Ilmiah Globe, 16 (1), 43-50 (2014)

3. R. Mahmood, R.A. Pielke, K.G. Hubbard, D. Niyogi, P.A. Dirmeyer, C. McAlpine, A.M. Carleton, R. Hale, S. Gameda, A. BeltránPrzekurat, B. Baker, R. McNider, D.R. Legates, M. Shepherd, J. Du, P.D. Blanken, O.W. Frauenfeld, U.S. Nair, and S. Fall, Land cover changes and their biogeophysical effects on climate. Int. J. Climatol. 34 : 929-953 (2014)
4. Cao Q, Yu D, Georgescu M, Han Z, Wu J. Impacts of land use and land cover change on regional climate: a case study in the agro-pastoral transitional zone of China. Environ Res Lett. 10 (2015)

5. Peraturan Menteri Kehutanan Republik Indonesia No 10 Tahun 2011 Tentang 6 (enam) Kebijakan Prioritas Bidang Kehutanan dalam Program Pembangunan Nasional Kabinet Indonesia bersatu II. (2011)

6. Hardjowigeno \& Widiatmaka. Evaluasi Kesesuaian Lahan dan Perencanaan Tataguna Lahan. Gadjah Mada University Press. Yogyakarta (2007)

7. Badan Standardisasi Nasional. Klasifikasi Penutup Lahan : SNI 7645 :2010

8. Kementrian Lingkungan Hidup dan Kehutanan. Pemantauan Sumber Daya hutan Indonesia. (2015)

9. A.A. Nawir, Murniati, L. Rumboko. Rehabilitasi Hutan Indonesia: Akan Kemanakah Arahnya Setelah Lebih dari Tiga Dasawarsa?. Bogor. Indonesia: Centre for International Forestry Research (2008)

10. I.L. Subro, Diversitas Anak Pohon di Taman Nasional Gunung Merbabu Jawa Tengah. J.Tek.Ling, Edisi Khusus Hari Bumi, 67-74 (2012) 